\title{
Nomenclatural and taxonomic notes on Alcmeone robusta (Butler) comb.n. (Hemiptera, Auchenorrhyncha, Membracidae)
}

\author{
Gabriel Simões de Andrade ${ }^{1}$
}

\begin{abstract}
Ceresa robusta Butler, 1877 is transferred to the genus Alcmeone Stål, 1867 and A. sinuata Fonseca \& Diringshofen, 1974 is considered its new synonym. KEY WORDS. Hemiptera, Auchenorrhyncha, Membracidae, Alcmeone, Ceresa
\end{abstract}

\section{Alcmeone robusta (Butler, 1877) comb.n.}

Figs 1-3

Ceresa robusta Butler, 1877: 216, pl. III, fig. 10. - Metcalf \& Wade, 1965: 866 (cat.). - Broomfield, 1971: 372 (tip.). - Kopp \& Yonke, 1979: 24 (list.).

Alcmeone sinuata Fonseca \& Diringshofen, 1974: 156, fig. 4; syn.n.

The examination of one photograph (slide) from the female holotype of Ceresa robusta, deposited in The Natural History Museum (London), and also the study of the descriptions of STÅL (1867) and BUTLER (1877), show that this species may be included in the genus Alcmeone Stål, 1867, by the pattern of venation of the fore wings characteristic of Darninae and by the peculiar conformation of the pronotum.

According BROOMFIELD (1971), the labels of the type are "Type", "Braz", "68.4" and "C. robusta; Butler Type.".

Also, observations on material safely identified as A. sinuata, described by FonseCA \& Diringshofen (1974) from Rio Vermelho, Santa Catarina, Brasil, suggest the new synonym proposed.

Material examined. 1 female, "Rio Vermelho, São Bento do Sul, 850 m., Santa Catarina, 15.IV.1974, Rank leg." (Department of Zoology, Universidade Federal do Paraná, Curitiba, Brasil).

ACKNOWLEDGMENTS. I am indebted to Dr. A.M. Sakakibara and Dr. J.S. Moure (Universidade Federal do Paraná, Curitiba, Brasil), for the original of the photographs.

1) Departamento de Ciências Biológicas, Universidade Estadual do Oeste do Paraná. Rua Universitária 2069, Caixa Postal 711, 85814-110 Cascavel, Paraná, Brasil. 


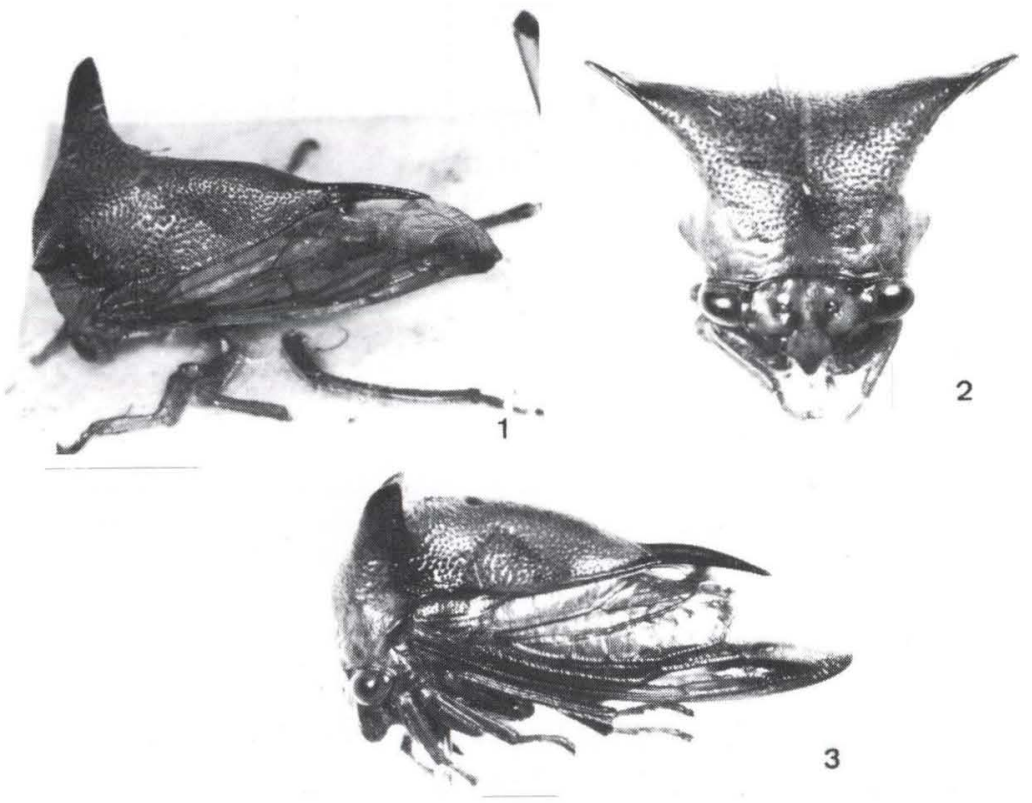

Figs 1-3. Ceresa robusta, female holotype, left lateral view; (2-3) Alcmeone sinuata, female, front and left lateral view.

\section{REFERENCES}

BROOMFIELD, P.S. 1971. A catalogue of the Membracid types (Homoptera: Membracidae) in the British Museum (Natural History). Bull. Br. Mus. nat. Hist. (Ent.) 25 (8): 325-86.

BUTLER, A.G. 1877. On various genera of the homopterous family Membracidae with descriptions of new species. Cistula ent. 2: 205-22.

FONSECA, J.P. \& R. VON DIRINGSHOFEN. 1974. Contribuição ao conhecimento dos

Membracídeos Neotrópicos (Homoptera: Membracidae, VII). Arq. Inst. Biol., São Paulo, 41 (4): 151-60.

STÅL, C. 1867. Bidrag till Hemipterernas systematik. Öfvers. K. VetenskAkad.

Förh. 24: 491-560.

Recebido em 31.X.1997; aceito em 01.III. 1999. 